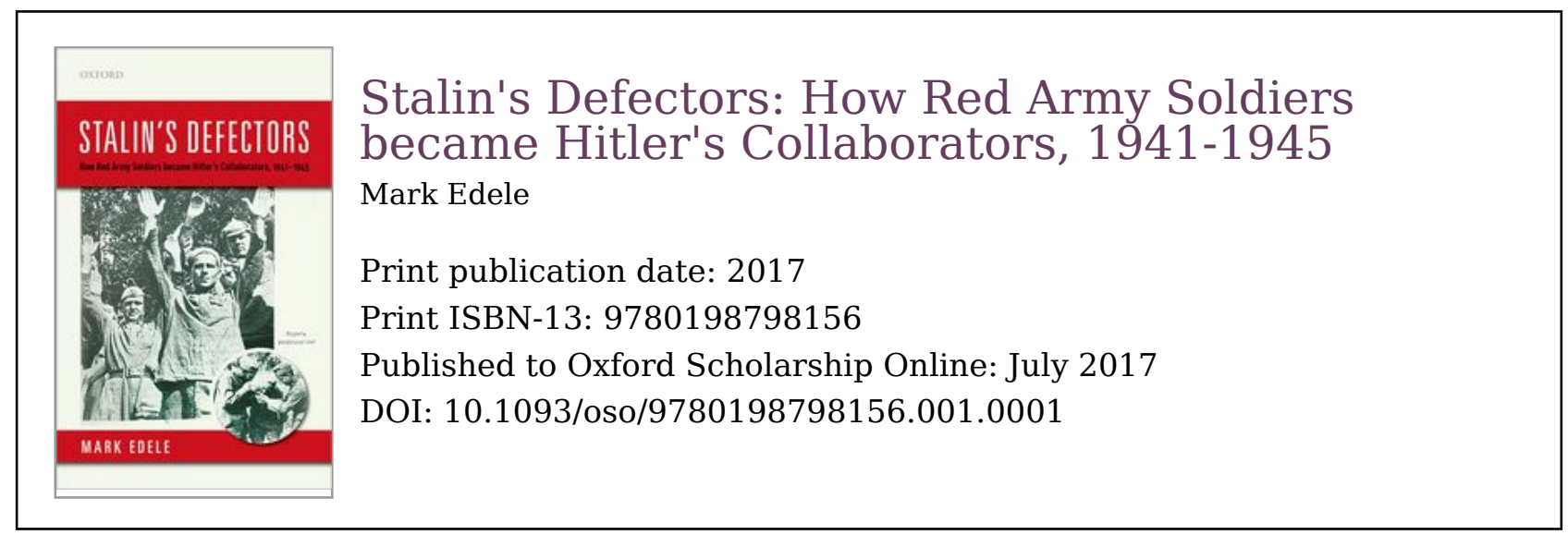

\title{
(p.vii) Preface
}

Mark Edele

An unparalleled number of Red Army soldiers deserted across the front line to give themselves up to Hitler's Wehrmacht. No other Allied army in the Second World War had such a large share of defectors among its prisoners of war (POWs). At the same time, the vast majority of Soviet soldiers who became POWs did not surrender voluntarily. Choosing examples for either extreme, contemporaries and later historians have reached far-reaching, but largely unsubstantiated conclusions about front-line surrender. Depending on their politics or their theories about Soviet pre-war life, they have either ignored front-line defection or declared that the vast majority of Soviet POWs gave up because they did not want to fight for Stalin. Surrender at the front line, or its absence, became an 'acid test' for Stalinism.

This book is the first systematic study of the phenomenon of front-line surrender to the Germans in the Soviet Union's 'Great Patriotic War', as most Russians still call the German-Soviet war of 1941-5. Based on both German and Soviet archival sources as well as on published and unpublished memoirs, diaries, and interviews from both sides of the front line, it investigates the extent, the context, the scenarios, the reasons, the aftermath, and the historiography of front-line defection. In doing so, it contributes to an ongoing scholarly debate about the Soviet experience of the Second World War, and the place this experience holds in the longer sweep of Soviet history.

Chapter 1 outlines the problematic, source base, and basic conceptual framework of this study and introduces Ivan Nikitich Kononov, one of our central protagonists. Chapter 2 investigates the extent of front-line defection, by which I mean the deliberate desertion across the front line. This chapter has been written largely for sceptics among specialist historians and can be safely skipped 
by readers who are already convinced of the significance of the phenomenon. They can jump ahead to the twin chapters which explore the obstacles Soviet soldiers faced when trying to defect (Chapter 3 ) before examining how these hurdles were overcome (Chapter 4 ). Who the men were who crossed the line is described in Chapter 5, while their motivations are investigated in Chapter 6, which closes the study of defection itself. The next three chapters are concerned with what happened to Stalin's defectors and their story after the initial deed was done. Chapter 7 describes the various paths these defectors took (p.viii) later in the war, in particular the widespread decision to collaborate with the Nazis. It also follows them through the end of the war and either back to the Soviet Union or into exile all over the world. Chapter 8 investigates what happened to their story after the war was over-an exercise in intellectual history and an investigation of the history of history writing. The implications of Soviet wartime defection for the current scholarly debate on the Soviet Union at war is the topic of Chapter 9. These final two chapters can be skipped by readers not interested in the politics of history writing and the genealogy of current debates. Unlike the rest of this book, they are mainly written for specialists.

This book thus combines military and political history with social and cultural enquiry, as well as historiography and intellectual history. It brings back together spheres of history writing which have been torn asunder by specialization: the histories of Stalinist society and its discontents, the Soviet and the German war efforts, of German occupation and resistance to it, of collaboration, of emigration, of repatriation, and finally of exile. In doing so, it contributes to all of these fields of enquiry, but also picks up a discussion among Soviet émigrés and western scholars in the immediate post-war period.

The central argument of this book is that while defection was a much more prevalent phenomenon in the Soviet military than in other Allied armies, it was motivated in complex ways. The most widespread sentiment animating attempts to cross the front line was a wish to survive this war. Disgruntlement with Stalin's 'socialism' was also prevalent among those who chose to give up and hand themselves over to the enemy. While politics thus played a prominent role in pushing people to commit treason, few desired to fight on the side of the enemy. Hence, while the phenomenon of front-line defection tells us much about the lack of popularity of Stalin's regime, it does not prove that the majority of the population was ready for resistance, let alone collaboration. Both sides of a long-standing debate between those who equate all Soviet captives with defectors, and those who attempt to downplay the phenomenon, then, overstress the significance of front-line defection. Instead, more recent research on the moods of both the occupied and the unoccupied Soviet population shows that the majority understood their own interests in opposition to both Hitler's and Stalin's regime. The findings of this book support such an interpretation. 
Five years ago I set out to write 'a little essay' on front-line defection, which would make sense of archival evidence I had inadvertently come across. The essay continued to grow, until I was finally forced to admit (p.ix) that it was a short book, not a long essay any more. During the half decade of struggling with this book, my daughter has grown from a toddler to a primary school child. As she grew up, Anna inspected books on the German-Soviet war littering the floor, the tables, and the bookshelves of my study. She repeatedly complained about a particularly gruesome Soviet propaganda poster in my university office: 'Papitake it down! I don't like it!' And during a hike in the Western Australian bush in 2012 , then 3 years old, she startled me with the question: 'Papi, in the olden days, when you were in Russia-did you also kill people?' My obsession with this war, then, has left traces in the mental world of my daughter beyond the usual refrain that daddy was hiding in his office writing something incomprehensible rather than engaging in more meaningful activity, such as chasing bugs in the garden, swimming in the river or the ocean, reading books about dragons, or playing hide-and-seek. Thankfully, Anna still believes that war is something which happened only in 'the olden days' and in 'the Soviet Union'-times and places of nearly mythical status. I hope that this sense of war as something far, far away will remain with her for the rest of her life. I dedicate this book to her in this spirit.

Anna is not the only person I have accumulated debts to while working on this book. The greatest of them all is to my wife, Debra McDougall, a comrade-inarms who has not deserted me, despite having to fight her own scholarly battles. I dedicate this book to her as well. My mother, Brigitte Edele, and my in-laws Carol and David McDougall helped again and again with daily life and child-care both during their frequent visits to North Fremantle, and while I was conducting research in Germany and the United States.

Beyond my family, I have benefited from the professional support from many institutions and individuals. Research and writing was made possible in part by a University of Western Australia Research Development Award (2010), an Australian Research Council Discovery Project Grant (DP130101215, 2013-15), an Australian Research Council Future Fellowship (FT140101100, 2015-19), and sabbatical leave from the School of Humanities, The University of Western Australia, in the first half of 2015. The Australian National University's School of History provided office space, library privileges, and afternoon tea during several months I spent as an academic visitor in Canberra in 2016. I would like to thank: Iva Glisic, research associate extraordinaire and reader of the entire manuscript; my research assistants Daria Rudakova and Vanessa Sofoulis, who helped gather materials; Jürgen Förster for showing me the ropes in the German military archive in Freiburg; the archivists of that same archive, in particular Nina Janz, for their suggestions of where to look; Benjamin Haas, whose expert assistance saved me several additional trips to (p.x) Freiburg; Tanya Chebotarev, the Curator of the Bakhmeteff Archive, for her invaluable help 
during my stays in New York; and USHMM's librarians, Vincent Slatt and Megan Lewis, for their support during my research in Washington. Benjamin Tromly shared copies of relevant NARA files, while Brandon Schechter equally generously provided copies from RGASPI. Both also gave me unpublished work to read, which helped enormously. When asked about the likely share of officers in Red Army front-line units, Brandon went above and beyond the call of duty. I could not have answered this question without his help. Oleg Beyda and Igor Petrov generously shared their then unpublished work on Kononov, and showed me the way to a major source collection and other materials I had not known. David Stahel saved me from misinterpreting a crucial number and shared archival notes putting it in the correct context. Elena Govor suggested checking 'my' defectors against newly available online databases, which led to several discoveries.

An early stab at some of the material was presented at the conference Homecomings: Experiences and Narratives of WWII Resistance Veterans and the Reconstruction of Postwar Europe, Birkbeck College, University of London, 2425 April 2015, as well as in the UWA Russian History Research Group Seminar on 22 May 2015. A more advanced paper was presented first at the 2015 Conference of the Australian Association for European History (AAEH) at the University of Newcastle, then at the History Seminar at the Australian National University, Canberra, in August 2016 and the Australian Defence Force Academy, Canberra, in September of the same year. This paper formed the basis for the publication of material from several chapters of this book as 'Not an Ordinary Man: Ivan Nikitich Kononov and the Problem of Frontline Defection from the Red Army, 1941-1945' in the Australian Journal of Politics and History 62, no. 4 (2016). I would like to thank all participants for their questions, comments, and critiques. In particular, Roger Markwick's feedback helped to strengthen the argument and Oleg Beyda's knowledge of my subject matter was invaluable. Sheila Fitzpatrick's gentle disagreement pushed me away from making a rather outlandish claim. My brilliant Honours students in my 2015 course on collaboration read an earlier version of the entire manuscript and bravely criticized its contents. Two of them, Georgia Oman and Amy Pracilio, quietly handed me sheets of paper after the end of this memorable seminar. They contained a list of silly mistakes and typos, which spared me considerable embarrassment later. The comments by three anonymous readers for Oxford University Press helped polish the final version. One of them revealed her identity subsequently, and, as Olga Kucherenko, added further commentary. Brandon Schechter and Benjamin Tromly also read the entire manuscript (p.xi) and provided extremely helpful feedback. Genevieve Earl helped enormously with creating the index.

My colleagues in the History Discipline at UWA have sustained me over the last decade. In particular, I would like to thank Andrea Gaynor, Jeremy Martens, Jane 
Lydon, and Robert Stuart for friendship, the sharing of gossip, coffee, or 'something stronger', as is so often required for sanity's sake.

Mark Edele

Kyiv

26 November 2016 (p.xii)

Access brought to you by: 